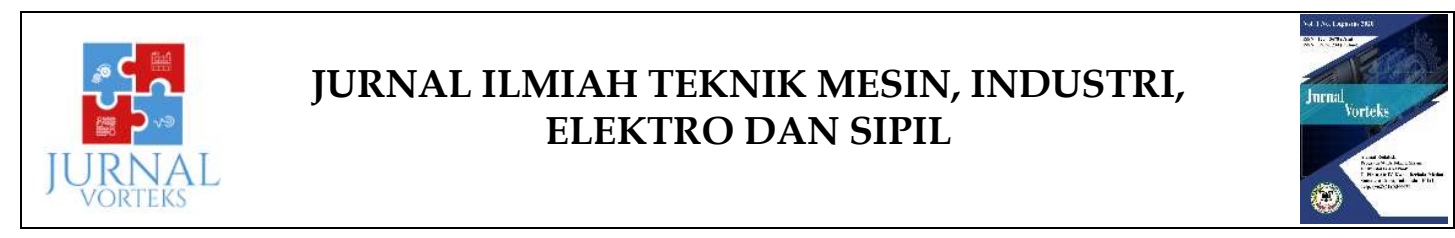

\title{
RANCANGAN KINCIR ANGIN PROTOTIPE 18 PU 400
}

\author{
Mawardi $^{1}$, Zufri Hasrudy Siregar ${ }^{2}$ \\ 1,2,Program Studi Teknik Mesin, Fakultas Teknik Universitas Al-Azhar \\ Jl. Pintu Air IV No.214, Kwala Bekala, Medan, Sumatera Utara- 20142 \\ 1. mawardi.ipc@gmail.com, ${ }^{2}$ rudysiregar7@,gmail.com
}

\begin{abstract}
ABSTRAK
Pemanfaatan energi alam seperti angin sangat dibutuhkan masyarakat luas mengingat bahan bakar yang semakin kompetitif. Kincir angin Prototipe 18 PU 400 idealnya dapat dijadikan model untuk kebutuhan masyarakat petani. Dari hasil rancangan kincir angin prototipe 18 PU 400 ini didapat Ring kecil penumpu sudu bagian dalam $19^{0}$ dan ring besar penumpu sebelah luar $7.3^{0}$. Daya kincir angin kecepatan putarnya sebesar 4.7 Hp. Debit (kapasitas) pompa teoritis prototipe kincir angin (Qth) sebesar 17 1/det. Debit (kapasitas) Pompa sebenarnya 5.1 1/det. Friction Losses pada pipa hisap adalah $0.003 \mathrm{~m}$. Friction Losses pada pipa tekan $8.01 \mathrm{~m}$. Debit (kapasitas) pompa teoritis (Qth) adalah 6.6 1/det. Debit (kapasitas ) pompa sebenarnya $\left(Q_{s}\right)$ adalah $1.9 \mathrm{l} / \mathrm{det}$. Hasil perhitungan Daya Pompa $\left(N_{p}\right)$ adalah $1.7 \mathrm{Hp}$.
\end{abstract}

Kata Kunci : Prototipe, Friction losses, pipa tekan, daya pompa dan pompa teoritis.

\section{ABSTRACT}

Utilization of natural energy such as wind is very needed many community, considering that fuel is increasingly competitive. Ideally, the 18 PU 400 prototype windmill can be used as a model for the needs of the farming community. From the design results of the 18 PU 400 prototype windmill, it is obtained a small ring for the inner blade $19^{\circ}$ and a large ring for the outer blade $7.3^{0}$. The rotating speed of the windmill is $4.7 \mathrm{Hp}$. The discharge (capacity) of the theoretical pump the windmill prototype (Qth) is $17 \mathrm{l} / \mathrm{sec}$. The actual pump discharge (capacity) is $5.1 \mathrm{l} / \mathrm{s}$. Friction Losses on the suction pipe are $0.003 \mathrm{~m}$. Friction Losses on the compressed pipe $8.01 \mathrm{~m}$. The theoretical pump discharge (Qth) is $6.6 \mathrm{l} / \mathrm{s}$. The actual pump discharge (Qs) is $1.9 \mathrm{l} / \mathrm{s}$. The result of the calculation of Pump Power (Np) is $1.7 \mathrm{Hp}$.

Keywords: Prototype, friction losses, pressure pipe, pump power and theoretical pump. 


\section{JURNAL ILMIAH TEKNIK MESIN, INDUSTRI, ELEKTRO DAN SIPIL}

\section{PENDAHULUAN}

Dewasa ini pemanfaatan potensi energi terbarukan (renewable energy) sangat gencar dilakukan baik dikalangan praktisi dunia industri dan sampai pada penelitian peneliti di kalangan profesi pendidikan. Potensi yang akan dibangun adalah dari potensi alam. Bahan bakar konvensional yang lazim dipakai seperti, minyak, gas, batu bara dan bahan hasil bumi lain yang masih merupakan sumber utama dalam menggerakkan roda permesinan dan komponen lain di dunia.

Permasalahnnya adalah bahan bakar konvensional tersebut dirasakan semakin berkurang dan cenderung habis. Untuk meningkatkan kepedulian terhadap anjuran hemat energi maka salah satu alternatif yang sangat efektif dan ekonomis yang dilakukan adalah dengan memanfaatkan energi alam yang dimanfaatkan langsung oleh masyarakat untuk menggerakkan peralatan tanpa melalui proses pembakaran dimana energi tersebut adalah energi angin. Sebenarnya pemanfaatan energi alam angin ini bukanlah hal yang baru, bahkan sejak tahun 1922 seorang sarjana di Finlandia bernama Sigurd J. Savonius menemukan model rotor turbin angin dengan memanfaatkan daya drag. Konstruksi turbin sangat sederhana, tersusun dari dua buah sudu setengah silinder [1].

Pemanfaatan energi angin ini akan diimplementasikan dalam bentuk kincir angin dan pemanfaatannya akan dirasakan oleh petani untuk persawahan dan manfaat lainnya yang lebih luas. Kincir yang akan dibuat adalah model Horizontal Axis Wind Turbine (HAWT), yang akan di fungsi alihkan ke pengairan area persawahan petani. Sebenarnya potensi angin di Indonesia tergolong sangat rendah, namun pemanfaatannya sangat dirasakan bagi petani. Tujuan Rancangan kincir angin prototipe $18 \mathrm{PU}$ 400 ini mengidentifikasi kecepatan angin minimum hingga maksimum dan selanjutnya diasumsikan memilih besar diameter silinder pompa serta laju kecepatan putar sudu pada waktu tertentu. Metode rancangan pembuatan model prototipe kincir angin ini menggunakan rasio perbandingan $\mathrm{P} / \mathrm{M}$ 200/3. Tema dari rncangan ini adalah rancangan kincir angin prototipe 18 PU 400. Satu cara yang ideal diterapkan di Kota Medandengan mempertimbangkan faktor keuntungan dan kerugian.

\section{TINJAUAN PUSTAKA}

Kincir Angin (wind mill) merupakan sebuah pesawat penggerak mula (primer mover) dimana angin dimanfaatkan untuk menggerakkan sudu kincir untuk selanjutnya ditransformasikan dalam satu bentuk energi mekanis guna menggerakkan putaran poros kincir. Poros dihubungkan mekanisme (crank mechanism) baik langsung atau dengan perantara roda gigi. Kincir angin ini nantinya dimanfaatkan sebagai tenaga penggerak untuk supply air ke persawahan petani.

Mulai tahun 1975, NASA mengelola program untuk Departemen Energi Amerika Serikat dan Departemen Dalam Negeri Amerika Serikat untuk mengembangkan turbin angin skala utilitas untuk tenaga listrik, sebagai tanggapan atas kenaikan harga minyak [2]. Pada tahun 1975 NASA merancang dan membangun turbin angin prototipe pertamanya, $100 \mathrm{~kW}$ Mod-0 di Sandusky Ohio, dengan dana dari National Science Foundation dan ERDA. Mod-0 dimodelkan setelah turbin penelitian dua bilah yang ringan oleh Ulrich Hütter dari Austria [3].

Kincir angin dibedakan dalam dua kategori yaitu berdasarkan aliran angin yang masuk ke sudu penggerak dan jumlah sudu penggeraknya. Berdasarkan aliran angin yang ke sudu penggerak kincir angin dibedakan pada kincir axial atau arah aliran angin paralel terhadap sumbu poros dan kincir radial arah aliran angn tegak lurus terhadap poros kincir. Berdasarkan jumlah sudu penggerak (blades) dibedakan oleh kincir dengan beberapa buah sudu antara $1-6$ sudu saja dan jumlah sudu banyak (multiple blades) terdiri dari $6,8,12,16,18$ blades danseterusnya.

Kapasitas kincir angin akan tergantung pada kondisi angin setempat. Jenis angin lokal yang berlangsung akan dipengaruhi oleh kondisi geografis permukaan bumi, yaitu lautan, hutan,

Hal 31 dari 43 


\section{JURNAL ILMIAH TEKNIK MESIN, INDUSTRI, ELEKTRO DAN SIPIL}

kota, padang rumput dan padang pasir. Angin yang ada berupa angin darat dan angin laut.

Disamping faktor kecepatan angin, kemiringan penghempas angin yaitu sudu sangat mempengaruhi kapasitas yang akan dihasilkan kincir. Lenkungan dibentuk $10 \%$ setiap penampang dengan pertimbangan yang efisien terhadap tekanan udara (air foil) dengan sifatsifat aerodinamika.

Kincir angin ini diambil rancangannya berdasarkan pengalaman keberhasilan penemu terdahulu tipe 16 PU 450 di Jl. Medan Tanjung Morawa, tahun 1988 oleh Bapak M. Noor El Husein dan Nick Van de Ven " Contruction manual of 12 PU 350 dan 12 PU 500 wind mill, Holland yang dikembangkan oleh Dutc Tool Foundation, dibawah pengawasan Universitas Teknologi Twente di negeri Belanda [4]. Selanjutnya penulis tambah 6 daun dengan pertimbangan karena kecepatan angin yang tidak terlalu besar di Indonesia dan juga mengatasi penurunan kecepatan rotor.

\section{METODOLOGI}

Metode perancangan kincir angin Pump Unit (PU) meliputi tahapan sebagai berikut:

1. Tempat, Waktu, Alat Bantu dan Bahan

Tempat yang dilakukan dalam mengambil data dan melakukan aktivitas penelitian ini adalah di kota Medan di Laboratorium Universitas Al Azhar.

Waktu yang dibutuhkan dalam menganalisa pengambilan data pada penelitian ini selama 6 bulan terhitung mulai September 2019 hingga Maret 2020. Bahan sudu diambil plat baja tipis ukuran panjang $(\mathrm{L})=2440$ dan Lebar $(B)=1220$ $\mathrm{mm}$ Bahan untuk rangka diambil plat siku baja standar ukuran L40 x 40 × 4 mm dan L50 x 50 x $5 \mathrm{~mm}$. Sebagai baut pengikat digunakan baut SS304/316, dan pipa baja untuk pompa air, agar tahan terhahadap oksidasi luar. Alat bantu berupa mesin las, mesin gerinda, mesin bor baja, palu, sebagaimana alat bantu pada sebuah bengkel teknologi pada umumnya. Plat seng dan plat baja serta pipa baja sebagai bahan dasar dalam pembuatan kincir angin ini. Alat transportasi dilapangan juga mendukung kegiatan penyempurnaan pembuatan kincir angin ini.
2. Pembuatan prototipe alat uji

Pembuatan menara bagian atas dimulai dengan memotong plat siku L40x40x4 mm, bersamaan dengan potongan kaki bagian menara L50x 50x5 $\mathrm{mm}$. Silinder pompa berupa pipa baja dipasangkan pada garis simetris ditengah tengan menara. Ujung kaki bagian atas di las menghimpit pipa Ø 4" x $2650 \mathrm{~mm}$ dengan jarak antara satu sama lain $650 \mathrm{~mm}$ dari posisi puncak.Balok penyambung kaki di pasang tiap sisi dan berguna juga sebagai anak tangga. Pekerjaan mengelas dimulai dengan mempertemukan potongan

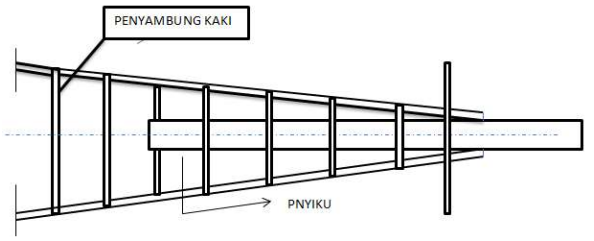

Gambar 1. Penyambung kaki dan menara bagian atas

Konstruksi kepala pada kincir angin berfungsi sangat vital karena selain sebagai beban rotor dan rotating equipment juga sebagai pengaman terhadap angin kencang. Baling baling didesain dari plat tebal $1 \mathrm{~mm}$ diambil dari ukuran $1200 \mathrm{x}$ $2400 \mathrm{~mm}\left(8^{\prime} \times 4^{\prime}\right)$ dimana tiap lebar didapat 4 buah daun, Kelengkungan pada daun baling baling sudu ditetapkan $10 \%$, pertimbangan efisiensi air foil terbaik.

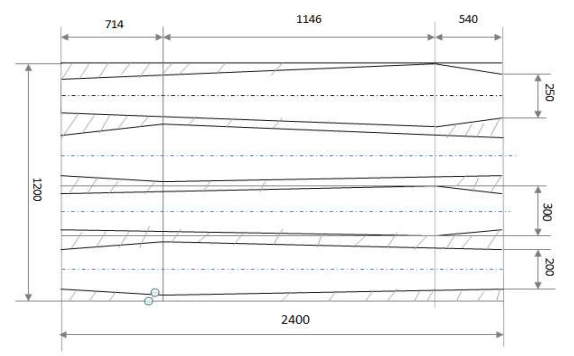

Gambar 2. Teknik pembagian daun baling baling

Diketahui panjang dinyatakan dalam $\mathrm{L}=2400$ mmdan lebar dalam $\mathrm{B}=300 \mathrm{~mm}$

Maka : $\mathrm{L} / \mathrm{B}=2400 / 300=1 / 8$.

Hal ini sesuai dengan Nick Van De Van dimana $\mathrm{L} / \mathrm{B}=2000 / 250$ adalah $1 / 8$ juga.

Hal 32 dari 43 


\section{JURNAL ILMIAH TEKNIK MESIN, INDUSTRI, ELEKTRO DAN SIPIL}

Konstruksi Ekor secara teknis gabungan plat siku no 16 dan 17 di las zig zag pada sisi atas dan bawah $25 \mathrm{~mm}$ tiap jarak $150 \mathrm{~mm}$ pangkal plat siku no. $1850 \mathrm{~mm}$, dapat dilihat pada gambar .3.

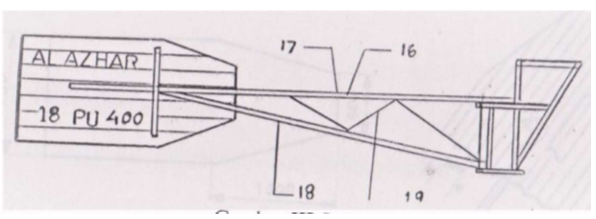

Gambar.3 Konstruksi Ekor

Menyetel potongan no. 1 dan no.2 bidang atas flens harusdatar. Ketika sambungan disatukan dengan potongan 12 dan no. 13 bentuknya huruf $\mathrm{Z}$ terbalik. Seperti terlihat pada gambar 4.

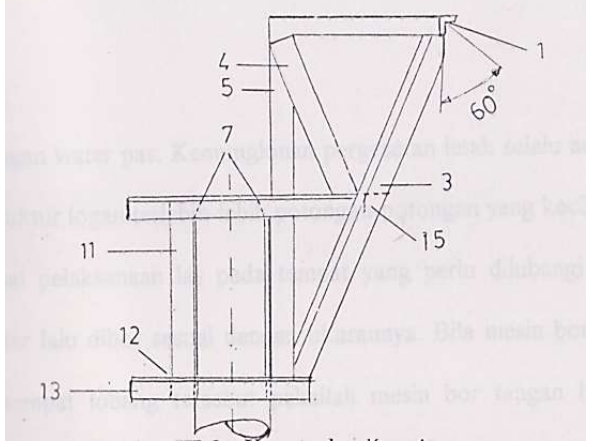

Gambar4 Konstruksi kepala

3. Parameter Desain

Kincir angin yang akan dirancang memilki ciri khas yaitu 18 Pump Unit 400 atau disingkat 18 PU 400. Didefinisikan sebagai kincir angin penggerak poma air yang memiki 18 buah sudu (baling baling) dengan panjang busur antar daun $400 \mathrm{~mm}$ pada cincin rotor diameter terkecil. Bagian utama kincir angin adalah menara, kontruksi kepala, kontruksi ekor, sayap ekor dan sayap pembantu, mekanisme engkol dan rotor. Panjang busur antar daun yang terdapat pada cincin dibagi sama menjadi:

$2 \times \pi \frac{1146}{18}=400 \mathrm{~mm}$

Tabel.1 Metode Perancangan

\begin{tabular}{lll}
\hline No & Identifiksi & Keterangan \\
\hline
\end{tabular}

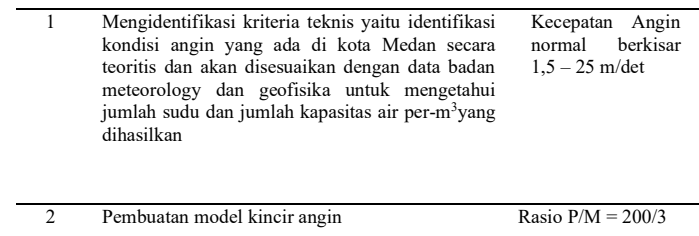

Menentukan besar kelengkungan dan kemiringan sudu sebagai contoh penumpu sudu pada bagian dalam, sisi tegak berbanding terbalik dengan sisi miring sehingga diketahui sudut kemiringannya. Diameter rataratadiambil dari sudut kemiringan yang paling tengah, dimana diameter sudu bagian dalam dan sudut kemiringannya berbanding terbalik dengan diameter ujung sudu beserta sudut kemiringannya $(\alpha)$ dan didapatkan sudut kemiringannya $(\beta)$. Persamaan dasar perhitungan kemiringan sudu diambil dari diameter rata-rata:

$\operatorname{tg} \beta_{1}=C_{1} / U_{1}=2 \operatorname{tg} \alpha_{1}=\beta_{1}=\operatorname{tg}^{-1} C_{1} / U_{1}$ (1)

Parameter bebas angin yaitu kapasitas dan kecepatan pada persamaan daya merupakan hubungan terbalik. Maksudnya untuk mendapatkan daya yang tetap, speed harus ditambah. Mendapatkan debit pompa teoritis (Qth), setelah didapat besar daya kincir akibat kecepatan putar, dikalikan dengan efisiensi mekanis. Ini berbanding terbalik berat jenis air dan head batang torak yang direncanakan.

Bahan sudu diambil plat baja tipis ukuran panjang sebagai berikut:

Panjang (L) : 2440

Lebar (B) : $1220 \mathrm{~mm}$

Dibagi $4 \quad$ : $300 \mathrm{~mm}$,

$\mathrm{L} / \mathrm{B}=2400 / 300$

$=1 / 8$

4. Rancangan Perhitungan

Berdasarkan data yang diambil dari data Badan Meteoroli, Klimatologi dan Geofisika Kota Medan, tahun 2020 dengan prakiraan angin lapisan 3000 feet kecepatan angin di Sumatera Utara sekitar $11 \mathrm{KT}$ (20.372 Km/Jam). Sebagai dasar perhitungan direncanakan [5]. Berdasarkan kondisi prakiraan angin dari BMKG dapat kita ambil dasar perhitungannya sebgai berikut:

Hal 33 dari 43 


\section{JURNAL ILMIAH TEKNIK MESIN, INDUSTRI, ELEKTRO DAN SIPIL}

- Kecepatan angin relatif minimum: $V_{\min }=$ $7 \mathrm{~km} / \mathrm{jam}=1.9 \mathrm{~m} /$ detik

- Kecepatan angin relatif maksimum: $V_{\min }=$ $20 \mathrm{~km} / \mathrm{jam}=5.5 \mathrm{~m} / \mathrm{detik}$

- Kecepatan angin relatif rata-rata: $\mathrm{V}_{\text {rata-rat }}=\frac{1.9+5.5}{2}=3.7 \mathrm{~m} /$ detik

Kecepatan angin rata rata di Sumatera Utara khususnya Kota Medan berdasarkan dari dasar perhitungan matematis rata rata kecepatan angin adalah $3.7 \mathrm{~m} /$ detik.

Didapat dari sumber cuaca dalam website yang dikeluarkan oleh accu weather menyatakan sebagaimana yang tertera pada Tabel.2 dibawah ini [6]. Hasil ini sejalan dengan penelitian yang dilakukan oleh Lusiani dan Teguh Wardoyo dengan judul "Analisis Arah Dan Kecepatan Angin Dengan Aplikasi Wrplots" pada salah satu titik di Perairan Cilacap dengan tujuan untuk menganalisis arah dan kecepatan angin dengan aplikasi pada Januari sampai Desember 2015. Data diperoleh dari BMKG Cilacap dengan rincian arah dan kecepatan angin setiap jam (24 jam) didapat 22 knots dengan tingkat persentase $29.0 \%$ dan bergerak di sekitar timur dan selatan [7].

Tabel 2. Kondisi Cuaca Sumatera Utara

\begin{tabular}{lll}
\hline \multicolumn{1}{c}{1} & \multicolumn{1}{c}{2} & \multicolumn{1}{c}{3} \\
\hline Kualitas Angin & $\begin{array}{l}\text { Titik Embun } \\
\text { (lumayan) }\end{array}$ & $23^{\circ} \mathrm{C}$ \\
Indekx UV Maks & $\begin{array}{l}\text { Tutupan Awan } \\
\text { (0 Rendah) }\end{array}$ & - \\
Angin & $\begin{array}{l}\text { Jarak Pandang } \\
\text { (BBD 6/km/jam) }\end{array}$ & $96 \%$ \\
Angin Kencang & $\begin{array}{l}7 \mathrm{~km} / \mathrm{jam} \\
93 \%\end{array}$ & $8 \mathrm{~km}$ \\
Kelembaban & $3100 \mathrm{~m}$ \\
\hline
\end{tabular}

Kondisi cuaca di Bandara Kuala Namu pada Januari 2020 dapat kita lihat pada tabel 3 . sebagai data masukan dasar matematis [8].

Tabel 3. Kondisi cuaca Bandara Udara Internasional Kuala Namu

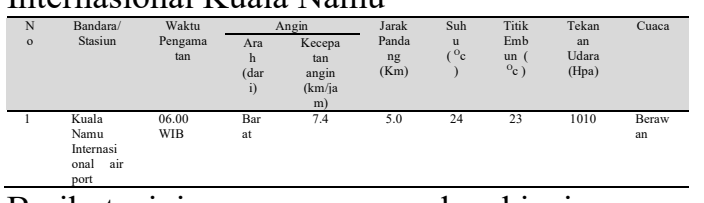

Berikut ini rancangan sudu kincir yang direncanakan, dapat dilihat pada gambar 3.4 berikut.
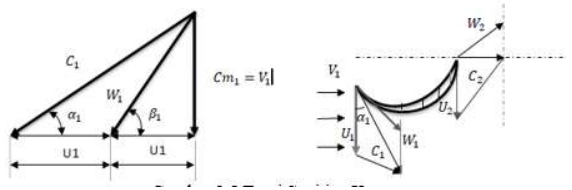

Gambar 4. Teori Segitiga Kecepatan

Dimana:

$U_{1}=$ Kecepatan keliling sudu

$C_{1}=$ Kecepatan absolut angin masuk

$W_{1}=$ Kecepatan relatif angin masuk

$\alpha_{1}=$ Sudut masuk mutlak

$\beta_{1}=$ Sudut masuk relatif

Persamaan berikut merupakan teori segitiga kecepatan:

$U_{1} / C_{1}=\operatorname{Cos} \alpha / 2$

$\operatorname{tb} \beta_{1}=C_{1} / U_{1}=2 \operatorname{tg} \alpha_{1}$

\section{HASIL DAN PEMBAHASAN}

Mekanisme engkol (rotating equipment) batang torak berupa kepala silang merubah gerak rotasi rotor menjadi gerak naik turun batang torak ini. Jenis pompa yang direncanakan pada pembuatan prototipe kincir angin ini termasuk kategori pompa torak. Mengingat prinsip dari kincir ini sebagai teknologi tepat guna di masyarakat sehingga konsep kesederhanaan diutamakan, sehingga dipilihlah pompa torak kerja tunggal. Dimana prisnsip kerjanya mengalirkan air ke persawahan petani melalui mekanisme kerja pompa kincir angin ini. Pada kecepatan angin menengah hingga tinggi, kincir angin ini dapat mengangkat beban hingga 150 kg setara dengan 2 orang dewasa. Kemampuan ini diasumsikan dalam pemilihan besar diameter silinder pompa yang direncanakan. Sebagai contoh dapat kita lihat pada persamaan berikut:

$D \leq k \sqrt{\frac{P}{H}}, d m$

Dimana:

$\mathrm{k}:$ konstanta turunan teoritis : $1.7-3.0$

diambil 3,0

$\mathrm{P}$ : gaya tarik pada kecepatan angin relatif rendah $50 \mathrm{~kg}$

$\mathrm{H}:$ Tinggi angkat pompa maksimum $=150 \mathrm{dm}$ $(15 \mathrm{~m})$

Sehingga batang torak yang direncanakan berdasarkan persamaan 3.6 diperoleh:

Hal 34 dari 43

JURNAL VORTEKS, Vol. 01 No. 01, Oktober 2020

p-ISSN :

Website : http://jurnal.alazhar-university.ac.id/index.php/vorteks

e-ISSN : 


\section{JURNAL ILMIAH TEKNIK MESIN, INDUSTRI, ELEKTRO DAN SIPIL}

$$
D=3 \sqrt{\frac{50}{150}} \rightarrow D=1,75 \mathrm{dm}=1.4 \mathrm{~m}
$$

Bedasarkan ketentuan praktis dimana bandingan antara langkah dan diameter silinder angka terbaik adalah antara 2-3, dalam hal ini diambil angka 2. Langkah torak terjauhpada mekanisme engkol kincir sebesar $240 \mathrm{~mm}$, sehingga diameter silinder pompa $240 / 2=120$ $\mathrm{mm}$. Diambil diameter standar dilapangan dipilih pipa Ø 5”(125 mm). Maka pompa torak yang direncanakan disebut $240 \mathrm{P} 125$.

1. Friction Losses pada pipa hisap

$H_{f s}=F \frac{L}{D} \times \frac{V}{2 . g}$

Dimana:

$\mathrm{H}_{\mathrm{a}}=$ Head losses pipa

Panjang pipa isap $=460 \mathrm{~mm}=0.46 \mathrm{~m}$, Diameter pipa isap $=125 \mathrm{~mm}=0.125 \mathrm{~m}$

Kecepatan pipa isap $=1.2-2.1$, diambl 1.2 $\mathrm{m} /$ det. $\mathrm{F}=$ faktor gesekan pipa isap

Sebelum mendapatkan harga F, Reynold Number (Re) harus diketahui dahulu, yaitu

$R_{e}=\frac{V \cdot D}{v}$

Dimana:

$\mathrm{V}:$ Kecepatan aliran $=1.2 \mathrm{~m} / \mathrm{det}$,

$\mathrm{D}$ : diameter pipa $0.125 \mathrm{~m}$

$\mathrm{v}:$ Viskositas kinematika air $0.93 \cdot 10^{-3} \mathrm{~m} / \mathrm{det}=$ $0.28 .10^{-5} \mathrm{~m} /$ det pada suhu $80^{\circ} \mathrm{F}$

Maka: $R_{e}=\frac{1.2 \mathrm{~m} / \operatorname{det} 0.125 \mathrm{~m}}{0.28 \times 10^{-5} \mathrm{~m}^{2} / \mathrm{de}}=5357$.

Untuk aliran turbulen ( $\mathrm{Re}>2300$ ). Bahan baja dipilih dengan keadaan permukaan $\mathrm{K}=0.0002 \mathrm{~m}$ $\frac{K}{D}=\frac{0.00002}{0.125}=0.00016$

Hubungan antara Re dan K/D dari Moody diagram diatas didapat $: \mathrm{F}=0.01$

Maka

$$
H_{f s}=0.01 \frac{0.46}{0.125} \times \frac{1.2^{2}}{2 \times 9.81}=0.003 \mathrm{~m}
$$

2. Friction Losses pada pipa tekan

$H_{1 d}=F \frac{L}{D} \times \frac{V^{2}}{2 . g}$

Maka,

$H_{1 d}=0.01 \frac{0.56}{0.06} \times \frac{1.2^{2}}{(2) 9.81}=0.007 \mathrm{~m}$

Maka Head Pompa (Hp) adalah:

$H_{P}=H_{f x}+H_{1 d}+H_{s}$

$003+0.007+8=8.01 \mathrm{~m}$
3. Debit (kapasitas) pompa teoritis (Qth)

$Q_{t h}=\frac{\pi}{4} \times \frac{D^{2}}{V} \times S$

$Q_{t h}=\frac{\pi}{4} \times \frac{0.125^{2}}{1.2} \times 0.6$

$$
=0.0066 \mathrm{~m}^{3} / \mathrm{det}=6.6 \mathrm{l} / \mathrm{det}
$$

4. Debit (kapasitas ) pompa sebenarnya $\left(Q_{S}\right)$

$Q_{s}=0.319 . Q_{t h}$

$Q_{s}=0.319 .6 .6=1.9 \mathrm{l} / \mathrm{det}$

5. Perhitungan Daya Pompa $\left(N_{p}\right)$

$N_{p}=\frac{\gamma \cdot H \cdot Q}{75 \cdot \eta P}$

$\gamma=$ berat jenis air $1000 \mathrm{~kg} / \mathrm{m}^{3}, \mathrm{H}=12 \mathrm{~m}$, $\mathrm{Q}=6.6 \times 10^{-3} \mathrm{~m} / \operatorname{det} \operatorname{dan} \eta P=60 \%$

Maka :

$P_{p}=\frac{P_{W}}{\eta_{P}} \quad \frac{0.37}{0.060}=6 \mathrm{KW}$

Maka daya pompa adalah :

$N_{P}=\frac{1000 \cdot 12 \cdot 6 \cdot 6 \cdot 10^{-3}}{75 \cdot 0.60}=1.7 \mathrm{Hp}$

6. Ring kecil penumpu sudu bagian dalam prototipe kincir angin

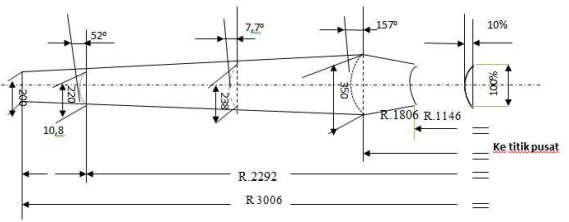

Gambar 5. Daun sudu kincir

$\operatorname{tg} \beta_{1}=\frac{\text { sisi tegak }}{\text { sisi miring }}$

$\operatorname{tg} \beta_{1}=\frac{157}{238} \quad \beta_{1}=\operatorname{tg}^{-1} \frac{77}{238} \quad \beta_{1}=19^{0}$

7. Ring Besar Penumpu sebelah luar prototipe kincir angin

$\operatorname{tg} \beta_{1}=\frac{77}{40} \rightarrow \beta_{1}=\operatorname{tg}^{-1} \frac{5.1}{40} \rightarrow \beta_{1}=7.3^{0}$

8. Sudut diameter rata-rata prototipe kincir angin

: $\operatorname{tg} \beta_{1}=\frac{C m_{1}}{U_{1}}$

$\operatorname{tg} \beta_{1}=\frac{111}{238} \beta_{1}=\operatorname{tg}^{-1} \frac{111}{238} \rightarrow \beta_{1}=25^{0}$

Hal 35 dari 43

JURNAL VORTEKS, Vol. 01 No. 01, Oktober 2020

p-ISSN :

Website : http://jurnal.alazhar-university.ac.id/index.php/vorteks

e-ISSN : 


\section{JURNAL ILMIAH TEKNIK MESIN, INDUSTRI, ELEKTRO DAN SIPIL}

9. Ujung Sudu prototipe kincir angin : $\operatorname{tg} \beta_{1}=2 \operatorname{tg} \alpha_{1}$

$$
\begin{gathered}
\frac{52}{200}=2 \operatorname{tg} \alpha_{1} \frac{52}{200}=\operatorname{tg} \alpha_{1} 0.26=\operatorname{tg} \alpha_{1} \\
\alpha_{1}=\operatorname{tg} \alpha_{1} \times 0.26 \rightarrow \operatorname{tg} \alpha_{1}=14.7^{0}
\end{gathered}
$$

Dijadikan sebagai dasar perhitungan diambil sudut kemiringan sudu pada diameter rata rata $25^{0}$.

$$
\begin{aligned}
& \operatorname{tg} \beta_{1}=2 \operatorname{tg} \alpha_{1} \frac{111}{238}=2 \operatorname{tg} \alpha_{1} \rightarrow \frac{0.47}{2} \\
&=\operatorname{tg} \alpha_{1} \rightarrow 0.24=\operatorname{tg} \alpha_{1} \\
& \alpha_{1}=\operatorname{tg} \alpha_{1} \times 0.24 \rightarrow \operatorname{tg} \alpha_{1}=13.5^{0}
\end{aligned}
$$

10. Jari-jari rata-rata prototipe kincir angin (Dm):

$$
\begin{gathered}
D m=\frac{R k+R b}{2} \times 2=\frac{1146+3006}{2} \times 2 \\
=4152 \mathrm{~mm}=4.152 \mathrm{~m} \\
W_{1} \operatorname{Cos} \alpha_{1}=U_{1} \rightarrow U_{1}=W_{1} \operatorname{Cos} \alpha_{1} \\
W_{1}=0.6 \times 2.7 \rightarrow \operatorname{Cos} \alpha_{1}=25^{0}=1.6 \\
U_{1}=1.6 \operatorname{Cos} 25^{0}=1.5 \\
n=\frac{U_{1} \cdot 60}{\pi \cdot D m}=\frac{1.5(60)}{3.14(4.152)}=7 \mathrm{rpm}
\end{gathered}
$$

11. Daya kincir angin Kecepatan Putar prototipe kincir angin

$N k \frac{W_{1} \cdot U^{2}}{g \cdot 75 \cdot \eta_{k}} \quad H p$

Dimana:

$W_{1}$ : jarak tempuh persatuan waktu atau agaya aliran udara di luasan sudu

$\eta_{k}:$ efisiensi kincir $=85 \%$

$$
\begin{gathered}
N k=(18 \times 1.6) 28=1224 \mathrm{~kg} / \text { detik } \\
U_{1}=2.57 \times 1.5 \operatorname{Cos} 25^{\circ}=3.5
\end{gathered}
$$

Maka:

$$
N k=\frac{1224(3.5)^{2}}{9.8 \times 75 \times 0.85}=4.2 \mathrm{Hp}
$$

12. Debit (kapasitas) pompa teoritis prototipe kincir angin (Qth)

$Q_{t h}=\frac{N_{k} 75 \cdot \eta_{k}}{\gamma \cdot H}$

Dimana:

$\eta_{k}$ adalah efisiensi kincir $=85 \%$

$\gamma$ adalah berat jenis air $1000 \mathrm{~kg}$

$\mathrm{H}$ adalah head yang direncanakan : 15 meter

$$
\begin{aligned}
Q_{t h}=\frac{4.2 \times 75}{1000 \times 0.85} \\
=15 \times \frac{10^{-2} \mathrm{~m}^{3}}{\text { detik }} \\
=17 \mathrm{l} / \text { detik }
\end{aligned}
$$

13. Debit (kapasitas) Pompa sebenarnya prototipe kincir angin $\left(Q_{a}\right)$

$$
Q_{a}=0.3 \text { Qth } \rightarrow=0.3 \times 17=5.1 \mathrm{l} / \text { detik }
$$

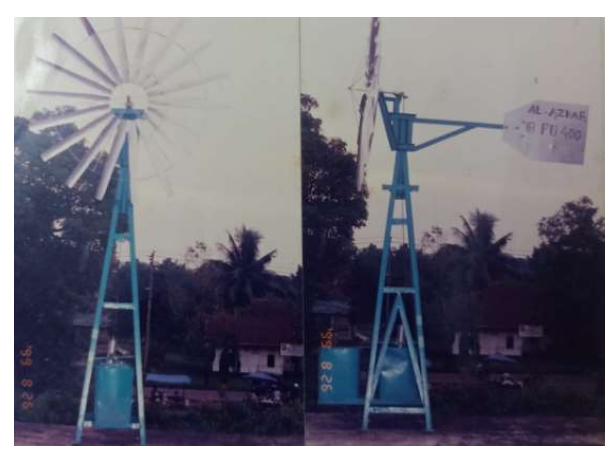

Gambar 6. Photo Konstruksi Menara

Berikut hasil data penelitian kincir angin prototipe 18 PU 400 dengan variasi beban 120 gr , 140 gr dan 170 gr dengan ketetapan waktu 60 detik. Menghasilkan kecepatan angin yang bervariasi dan putaran sudu yang bervariasi. Pelaksanaan penelitian dilakukan di gedung dengan ketinggian 10 meter. Sehingga menghasilkan data data real dilapangan, seperti terlihat pada tabel 4.1 berikut ini.

Tabel 4. Kincir angin prototip $18 \mathrm{PU} 400$ Beban 120 gr

\begin{tabular}{|c|c|c|c|c|c|c|}
\hline No & Beban & $n_{\text {sudu }}$ & $\begin{array}{c}\mathrm{T} \\
(\mathrm{detik})\end{array}$ & $\begin{array}{c}V_{\text {angin }} \\
\mathrm{m} / \text { detik }\end{array}$ & $\begin{array}{c}n_{\text {rumus }} \\
(\mathrm{rpm})\end{array}$ & $\begin{array}{c}N_{k} \\
(\mathrm{Hp})\end{array}$ \\
\hline 1 & 120 & 26 & 60 & 1.2 & 26 & 0.03 \\
\hline 2 & 120 & 27 & 60 & 1.3 & 28 & 0.04 \\
\hline 3 & 120 & 38 & 60 & 1.7 & 38 & 0.13 \\
\hline 4 & 120 & 39 & 60 & 1.8 & 39 & 0.16 \\
\hline 5 & 120 & 41 & 60 & 1.9 & 42 & 0.20 \\
\hline 6 & 120 & 45 & 60 & 2.0 & 45 & 0.26 \\
\hline 7 & 120 & 48 & 60 & 2.2 & 48 & 0.36 \\
\hline 8 & 120 & 52 & 60 & 2.3 & 51 & 0.54 \\
\hline 9 & 120 & 53 & 60 & 2.4 & 53 & 0.59 \\
\hline 10 & 120 & 54 & 60 & 2.5 & 55 & 0.62 \\
\hline 11 & 120 & 57 & 60 & 2.6 & 57 & 0.72 \\
\hline 12 & 120 & 62 & 60 & 2.8 & 62 & 0.98 \\
\hline 13 & 120 & 66 & 60 & 3.0 & 66 & 1.28 \\
\hline 14 & 120 & 71 & 60 & 3.2 & 71 & 1.73 \\
\hline 15 & 120 & 72 & 60 & 3.3 & 73 & 1.90 \\
\hline 16 & 120 & 75 & 60 & 3.4 & 75 & 2.10 \\
\hline 17 & 120 & 77 & 60 & 3.5 & 77 & 2.40 \\
\hline 18 & 120 & 79 & 60 & 3.6 & 79 & 2.60 \\
\hline 19 & 120 & 85 & 60 & 3.8 & 80 & 3.40 \\
\hline 20 & 120 & 86 & 60 & 3.9 & 86 & 3.70 \\
\hline
\end{tabular}

Hal 36 dari 43 


\section{JURNAL ILMIAH TEKNIK MESIN, INDUSTRI, ELEKTRO DAN SIPIL}

Dari Tabel diatas hubungan antara kecepatan angin dan putaran sudu dapat dilihat pada grafik berikut.

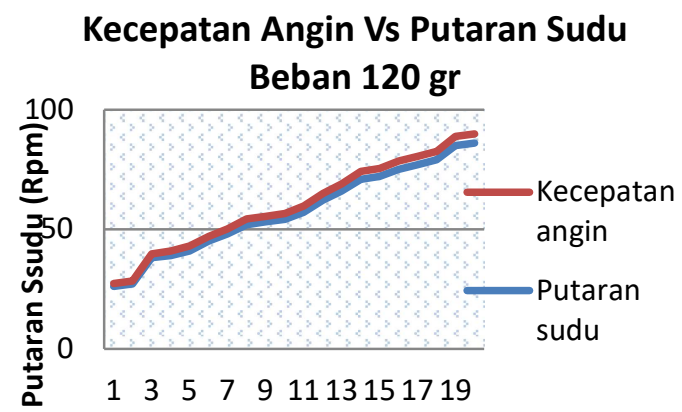

Gambar 7. Grafik Kecepatan Angin Vs Putaran sudu

Tabel 5. Kincir Angin Prototip 18 PU 400 Beban 140 gr

\begin{tabular}{|c|c|c|c|c|c|c|}
\hline No & Beban & $n_{\text {sudu }}$ & $\begin{array}{c}\mathrm{T} \\
\text { (detik) }\end{array}$ & $\begin{array}{l}V_{\text {angin }} \\
\mathrm{m} / \text { detik }\end{array}$ & $\begin{array}{r}n_{\text {rumus }} \\
\text { (rpm) }\end{array}$ & $\begin{array}{c}N_{k} \\
\text { (Hp) }\end{array}$ \\
\hline 1 & 140 & 32 & 60 & 1.5 & 33 & 0.1 \\
\hline 2 & 140 & 42 & 60 & 1.9 & 42 & 0.2 \\
\hline 3 & 140 & 44 & 60 & 2.0 & 45 & 0.3 \\
\hline 4 & 140 & 47 & 60 & 2.1 & 46 & 0.4 \\
\hline 5 & 140 & 50 & 60 & 2.3 & 51 & 0.5 \\
\hline 6 & 140 & 53 & 60 & 2.4 & 53 & 0.6 \\
\hline 7 & 140 & 55 & 60 & 2.5 & 55 & 0.7 \\
\hline 8 & 140 & 56 & 60 & 2.6 & 57 & 0.7 \\
\hline 9 & 140 & 57 & 60 & 2.6 & 58 & 0.8 \\
\hline 10 & 140 & 58 & 60 & 2.7 & 59 & 0.9 \\
\hline 11 & 140 & 61 & 60 & 2.8 & 61 & 1.0 \\
\hline 12 & 140 & 62 & 60 & 2.8 & 62 & 1.2 \\
\hline 13 & 140 & 67 & 60 & 3.1 & 67 & 1.6 \\
\hline 14 & 140 & 69 & 60 & 3.1 & 69 & 1.8 \\
\hline 15 & 140 & 70 & 60 & 3.2 & 70 & 1.9 \\
\hline 16 & 140 & 71 & 60 & 3.2 & 71 & 2.0 \\
\hline 17 & 140 & 72 & 60 & 3.3 & 72 & 2.1 \\
\hline 18 & 140 & 73 & 60 & 3.3 & 73 & 2.2 \\
\hline 19 & 140 & 74 & 60 & 3.4 & 75 & 2.5 \\
\hline 20 & 140 & 111 & 60 & 5.0 & 110 & 3.5 \\
\hline
\end{tabular}

Dari Tabel 5. diatas hubungan antara kecepatan angin dan putaran sudu dapat dilihat pada grafik berikut.

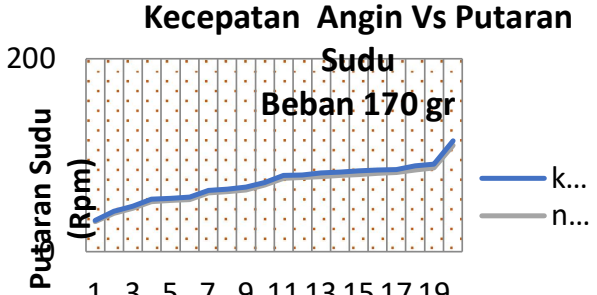

$\begin{array}{llllll}1 & 3 & 5 & 7 & 9 & 11 \\ 13151719\end{array}$

Gambar 8. Grafik Kecepatan Angin Vs Putaran sudu

\section{KESIMPULAN}

Kesimpulan yang dapat diambil dari penelitian ini adalah:

1) Kecepatan angin merupakan konsekwensi logis, namun kemiringan sudu yang memenuhi syarat besar pengaruhnya terhadap kapasitas yang ingin dicapai.

2) Pemanfaatan potensi renewable energi seperti angin sangat diperlukan dimasa mendatang mengingat bahan bakar yang semakin terkuras.

3) Rancangan kincir angin prototip $18 \mathrm{PU}$ 400 adalah sosok yang ideal untuk daerah sub tropis.

4) Masih terbuka luas pengembangan model rasio awal dan aplikasi dalam bentuk prototipe yang bervariasi.

5) Penelitian simulasi menggunakan aplikasi komputar bisa dilakukan pada model kincir angin jenis ini.

\section{UCAPAN TERIMAKASIH}

Pada kesempatan ini izinkan penulis mengucapkan ribuan terima kasih kepada:

1) Dekan Fakultas Teknik dan Kaprodi Teknik Mesin Universitas Al Azhar yang telah mendukung penulisan ini

2) Seluruh rekan tim yang tidak bisa disebutkan satu persatu yang ikut andil dalam penelitian ini.

\section{Referensi}

[1]. Sigurd Johannes Savonius, https://en.m.wikipedia.org/wiki/Savonius wind_turbine (2 November 1884 - $31 \mathrm{Mei}$ 1931) 


\section{JURNAL ILMIAH TEKNIK MESIN, INDUSTRI,}

ELEKTRO DAN SIPIL

[2]. Peter Asmus, Reaping the wind: how mechanical wizards, visionaries, and profiteers helped

shape our energy future Island Press, 2001 ISBN 1-55963-707-2 pages 54-56

[3]. http://www.eoearth.org/article/H\%C3\%BC tter,_Ulrich Ulrich Hütter 2008

[4]. Nick Van de Ven, Contruction Manual of 12 PU 350 and 12 PU 500 Wind Mill, Holland,1982

[5]. https://www.bmkg.go.id: 28 September 2020

[6]. https://www.accuweather.com/id/id/medan /211298/hourly-weather-forecast/211298

[7]. Lusiani dan Teguh Wardoyo, Analisis Arah Dan Kecepatan Angin Dengan Aplikasi Wrplots, Bahari Jogja, Volume XV Nomor 25, Juli 2017.

[8]. https://www.bmkg.go.id/cuaca/ prakiraan cuaca.bmkg 